\title{
THE INSTITUTION OF THE CIVIL PARTNERSHIP
}

\section{P. TĂRCHIL Ă}

\author{
Petru Tărchilă \\ Faculty of Humanities and Social Sciences \\ "Aurel Vlaicu" University of Arad, Arad, Romania \\ *Correspondence: Petru Tărchilă, "Aurel Vlaicu” University of Arad, Arad, Romania \\ E-mail: ijjs@yahoo.com
}

\begin{abstract}
:
Currently, within the territory of 21-member states of the European Union, live couples in civil partnership, couples which form families outside the judicial institution of marriage. In Romania as well, around 4\% of couples live in a type of civil partnership popularly named "concubinage" and, from their perspective, they form a family, they have children who are recognized by both parents and the patrimonial goods earned throughout their cohabitation represent common property, in a condominium. Although the initiative of the "civil partnership" has been repeatedly proposed, the Romanian Parliament rejected the idea of its judicial regulation, and recently, perhaps due to the legislative harmonization of this aspect with EU law, the Romanian Senate will debate a project of normative act in this domain. The legislative initiative would approve the unit of will of two people who willingly decide to cohabitate, regardless of whether the couples are made up of heterosexual couples or couples made up of people of the same sex.
\end{abstract}

KEYWORDS: JUDICIAL INSTITUTION, CIVIL PARTNERSHIP, NORMATIVE ACT, PUBLIC RIGHT, PRIVATE RIGHT, JUDICIAL RELATION, JUDICIAL NORM

\section{THE EVOLUTION OF THE INSTITUTION OF CIVIL PARTNERSHIP}

\subsection{The institution of civil partnership}

The senators will debate publicly an initiative which regulates the civil partnership in our country, a contract between two people who decide to cohabitate although they are heterosexual people or couples made up of people of the same sex. The legislative initiative is based on the argument of the recognition of these families outside the sphere of marriage, a recognition already made by 21 -member states of the European Union. The civil partnership, known popularly as concubinage, is situated, from the perspective of its previsions in the field of civil law. The senators say that around $4 \%$ of the population lives in such an arrangement according to recent surveys, so it is only normal that these couples should receive rights like any other families. According to the legislative project, the civil partnership is signed by two partners of common agreement, who are of or over the age of 18 , in the presence of a public notary from the circumscription of the Court of Apel in the area where at least one of the couple's members lives. If the two people decide to cohabitate in a civil partnership somewhere abroad, the agreement will be signed at the embassy or at the consulate of the respective state. The registrars will register all such contracts in a Register of Evidence of Civil Partnerships. In a period of 3 days after handing in the papers, the registrar will display the personal details of the two partners so that any person who may have anything against the signing of this agreement may contest it.

\section{Art. 5}

\subsection{The stipulations of the legislative project of the civil partnership}

b) at least one of the partners must be a Romanian citizen, or a foreign citizen or apatheid living in Romania 
c) neither of the partners should be married or part of another civil partnership

Art. 6 - The civil partnership cannot be signed if the future partners do not declare that they have mutually communicated their state of health."

The conditions in which the civil partnership cannot be signed are those from the civil law, namely between relative of up to the fourth degree, between a person who adopts and his/her ascendents or the person who is adopted and his/her children, between a tutor and the person under his/her tutelage, an underaged person, or between people who do not have mental judgement.

Those who agree to sign a civil partnership will have the same rights as those who are married - their incomes will be commonly considerate within the calculus of the minimum guaranteed income, and in the case of contracting a bank loan both incomes will be taken into consideration.

Art. 21

(1) The medical services required by a partner who does not possess medical insurance may be given from the medical insurance of the other civil partner.

(2) If one of the partners is hospitalized, the other partner is considered his/her kin."

Even in the case of the death of one of the partners, the rights of the survivour are in accordance with the Civil Code - he/she will inherit the common goods accumulated throughout the partnership. Moreover, the survivor has the right to a full inheritance if the deceased does not have heirs among his/her relatives. The survivor also has the right to a survivor pension, other rights of social insurance or of the legislation in the field.

A civil partnership may be ended by common accord again at the registrar's or unilaterally within 30 days from the date of the registration of the application of the partner wishing to end the agreement. The common goods are split of mutual accord, and in case of disagreement, the partners will address the court. The court is also the one which will decide in the case of disagreements between partners who have children born during the period of their civil partnership.

\section{A MODEL OF CIVIL PARTNERSHIP IN SWISS LAW}

\subsection{The legal conditions which must be fulfilled by both partners}

The civil partnership engages the partners of the same sex or of different sexes to a life of a couple and common responsibilities. They owe each other support and mutual respect. The Swiss law demands the cumulative fulfillment of the following compulsory conditions:

- Both partners should have at least 18 years of age and they must be capable of discernment

- They cannot be already married or in a civil partnership

- The people who are under tutelage must have the permission of their legal representative

- There cannot be a direct parental relationship between the partners. There cannot be a civil partnership between siblings, children and natural or adoptive parents and grandparents

- One of the partners must have a Swiss nationality and must reside in Switzerland

- The partners who do not have a Swiss nationality and do not live in Switzerland either cannot form a civil partnership with people of the same sex.

2.2. The procedure and the documents required by the institutionalization of the partnership

The partners must address the Civil Registry in the town or city where they reside, which will provide them with an application suitable to their request.

\section{Necessary documents}

For Swiss citizens

- An individual certificate of registry (it can be obtained from the Civil Registry in their place of origin) 
- A permit or certificate of residence (it can be obtained from the Population Records Office)

- A passport or identity card

For foreign citizens

- A permit of residency

- A birth certificate with details about the parents

- A passport or document of origin (obtained from the country of their origin)

- An individual certificate of registry (containing details about their civil state, divorce, the death certificate of the partner or the confirmation of the dissolution of the civil partnership)

- Refugees or people who demand asylum must present, apart from the passport or certificate of origin, a new certificate recently emitted about their status of refugees or solicitors of asylum. The partners prepare the necessary documents and report personally to the registrar where they are eligible to register their partnership. After the partnership has been authenticated, the partners receive the partnership certificate. The registrar demands a fee for the registration of the partnership (preliminary procedures, the authentification of the partnership) and for the delivery of the documents.

A viable partnership contracted abroad is recognized in Switzerland if it is in accordance with the Swiss principles of law. The partnership is registered in the "Infostar" civil registrar if one of the partners has Swiss nationality or resides in Switzerland. The application for recognition must be handed in at the Swiss representance (the embassy or consulate), along with the documents concerning the respective civil partnership.

\subsection{The judicial effects of the Partnership}

\section{a. Civil status}

The civil status must be indicated in the administrative documents, in this case, the civil partnership. If one of the partners dies or if the partnership is dissolute, the new civil status will be "dissolved partnership".

b. The conjugal residence

When they register their partnership, both partners engage in a common life. They decide to live together in one, two or more common homes. Neither of the partners can yield or terminate the home contract without the approval of the other partner.

c. The name

A civil partnership hasn't got an impact on the name of the partners, regardless of their origin. The foreign partners who live in Switzerland may ask the registrar to regulate their name in their country of origin (for instance Germany or the Scandinavian countries). The right of these countries, in accordance with Swiss rights, permits the partners to have the same name.

d. Citizenship and patrimonial goods

In order for a partner to obtain the Swiss citizenship, the law does not state a simple possibility of naturalization, as is the case of foreign spouses of Swiss citizens during marriage.

Each partner has the free right over his/her goods and is responsible for his/her debts. This system corresponds to the matrimonial right of sharing goods. Each partner must inform the other, at his request, about his income, goods and debts. At the request of one of the partners, a judge can force the other partner or a third party to offer relevant information and present the necessary documents.

In case the partnership is dissolved, the partners may convene over a set of specific rules and decide, for instance, that actives are shared according to the norms of the matrimonial regime on participation to acquisitions. As for the contract concerning inheritence, this is viable only if it is authenticated by a public notary. In the case of taxes and succession, the rules of matrimony apply to the civil partnerships. In case one of the partners 
dies, the remaining partner has the judicial status of widow/widower when it comes to the insurance offered by the Swiss services and the occupational pension. Anyone living in or owning the common residency of the couple must be informed of the couple's civil status. Hence, in case the renting contract is dissolved, both partners will be informed and the dissolution will be viable.

\section{e. Children}

People who are engaged in a civil partnership cannot adopt children and cannot use medical reproduction procedures. Moreover, the children of one of the partners cannot be adopted by the other partner either. In case one of the partners has children, the other must support him/her in the fulfillment of the obligation of diligence and in fulfilling parental authority in a reasonable manner and must represent him/her in case the circumstances demand it (an illness or absence).

$\mathrm{f}$. The dissolution of the partnership

The two partners may jointly demand the dissolution of the partnership. Moreover, each of them may demand it if they live separately for at least one year. As in the case of a divorce, the honoraries of the partners are shared. After the dissolution of the partnership, each of the partners is responsible for his/her alimony. If one of the two partners has not worked or has not exercised a lucrative activity to compensate for chore division, he may ask the other partner for a pension until the moment he/she will be able to support him/herself. Partners registered by a country which is a member of the EU or AELS or a third state receive a residence permit, respectively of residency, in the same conditions as a spouse in the given countries.

\subsection{Registered partnerships}

In numerous EU countries people may officialize their relationship without getting married by means of a registered partnership (also called civil partnership). The registered partnership offers the partners the chance to officialized their relationship in front of the competent authorities in their country of residency.

In this field, the law features significant differences from one country to the next - in some states this form of union does not exist or, if it has been officialized in another country, is not fully recognized. When more European countries are involved, for instance because the partnership was registered abroad or because the partners moved away after its registration, they must check the law of the country where the partnership was registered. This will have significant consequences upon the rights and obligations of the partners. In some EU states, the registered partnership is considered the equivalent of or compatible with marriage. There are also states whose legislation does not judicially regulate the institution of the civil partnership.

The EU countries whose legislation does not feature registered partnerships:

- Bulgaria

- Letonia

- Lithuania

- Poland

- Romania

- Slovakia

In the countries where the registered partnership is equivalent to marriage, the partners have the same immigration rights: thus, the registered partnership may follow you if you move to one of the given countries. The countries which allow marriages between people of the same-sex also generally recognize the registered partnerships signed in other countries by people of the same sex. In countries where the law provides a form of registered partnership but does not provide same-sex marriages, same-sex couples who married abroad will generally benefit from the same rights as the registered partners. European citizens who are financially dependent on their registered partners must solicit the right of residence from the authorities of the country where the couple settles, based on their right to accompany their 
partner. For citizens of third party countries, the registered partnership is essential to obtain the right to live in the EU. Couples who settle in a country which does not recognize registered partnerships will be considered as having a long-term relationship attested accordingly. Consequently, the authorities of the host-country must facilitate the entrance of the partner and his chances of obtaining the residence permit. The property and support pension rights in the case of registered partners do not apply in all EU countries: the rights which derive from a partnership registered in a country may differ significantly in another country.

\section{THE RIGHT OF POSSESSION OF GOODS IN THE CASE OF CONCUBINAGE IN ROMANIAN LAW}

3.1. The previsions of the new Romanian Civil Code regarding the right of possession of goods in the case of concubinage

In the relationships between concubines the source of coproperty cannot be neither the legal inheritance nor the law (because a special regime which makes derogations from the common right is reserved only to spouses), nor the intrusion, but only the convention of the parties, be it expressed or tacit, but only if it is unequivocal. The inexistence of a convention of common acquisition of goods enunciated in action by the parties in process is not mainly demonstrated by the absence of the probatory instrument in this regard, respectively of a disposition (justly supposing that the close relationship between them has prohibited, from a moral perspective, the preconstitution of certain documents), but by the fact that there hasn't been a certain and undoubted proof that the parties intended to acquire these goods as common property. The concubinage or the consensual union of two people is not reglemented in the Romanian civil code, neither are non-patrimonial personal relationships, nor the patrimonial relationships between concubines. Hence, the judicial regime of the goods acquired by the spouses, namely the condominium property, is not applicable to concubines, regardless of the length of their cohabitation. The presumption of a community of goods stated by art 30 of the Family Code is only applicable to spouses. Thus, in the situation of the concubines and their patrimonial relationships, we are dealing with an eventual situation of relative coproperty in the case of each good commonly acquired, which involves the demonstration, in the case of a separation, of each party's contribution to each individual good and not his/her contribution to the universality of the patrimony, as in the case of spouses. The specific of patrimonial relationships between concubines is the proof of their contribution to each good separately and, cumulatively, their intention of commonly acquiring goods according to art. 1294, art. 1295 corroborate with art. 1171-1173 of the Civil Code, the good are the property of the buyer, attested with the purchase document, in this case selling-buying contracts.

\section{CONCLUSIONS}

As a consequence of trying to harmonize legislatively the member states of the EU, the Romanian Senate will debate a project of a normative act in the field of the civil partnership. This legislative initiative would consolidate de union of will of the two people who decide to cohabitate out of common agreement, be them heterosexual or same-sex couples. The civil partnership, commonly known as concubinage, is part of the category of civil law from the perspective of its predispositions. Senators say that about $4 \%$ of the population lives in such a way, according to recent surveys, so that these couples should indeed be given rights like any other family. According to the legialative project, the civil partnership is signed by common agreement by two partners who are over 18 in the presence of a public notary from the area of the Appeal Court in whose circumscription where at least one of them resides. If the two people decide to cohabitate in a civil partnership somewhere abroad, the contract will be signed at the embassy or consulate of the given state. The public notary will register these contracts in a Register for the evidence of civil partnerships. Three 
days after presenting the necessary document, the public notary will display the personal details of the two partners so that any person who may have anything against the signing of the contract can contest it.

\section{BIBLIOGRAPHY}

1. Bârsan, C.,2009, Civil Law. General Considerations and People, Hamangiu Publishing House, Bucureşti.

2. Beleiu, Gh., 2009, Romanian Civil Law, Universul Juridic Publishing House, Bucharest.

3. Beleiu, Gh., 2010, Romanian Civil Law. Introduction in Civil Law. The Subjects of Civil Law, Şansa Publishing House, Bucharest.

4. Boroi, G.2010, Civil Law. General Considerations. AII Beck Publishing House, Bucharest.

5. Craiovan I.,2001, The General Theory of Law Teoria generală a dreptului, Sibila Publishing House, Craiova.

6. Deak F., Cărpeanu G., 1993, Drept civil. Partea generală. Universităţii Bucureşti Publishing House.

7. Poenaru E., 2009, Drept civil. Partea general. Persoanele. C.H. Beck Publishing House, Bucharest.

8. Pop L., 2010, Tratat de drept civil, Cordial Lex Publishing House, Cluj-Napoca.

9. Pop T., 1994, Drept civil, Persoanele fizice şi persoanele juridice, Lumina-Lex Publishing House, Bucharest.

10. Tărchilă P., Drept civil, Partea generală şi Persoanele. Tutimex Publishing House, 2016, Arad. 